\title{
PENERAPAN MODEL COOPERATIVE LEARNING DALAM UPAYA PENINGKATAN PRESTASI BELAJAR PESERTA DIDIK MATERI PELAJARAN EKOSISTEM PADA KELAS X.5 MA NEGERI I METRO LAMPUNG TIMUR
}

\author{
Mursida \\ MA Negeri I Metro Lampung Timur \\ E-mail: mursida_faris@yahoo.com
}

\begin{abstract}
The development of learning model from time to time continue to change. In line with the approach of Constructivism in learning, one of the learning models that is now a lot of response is a model of cooperative learning. Learning model that is applied related to student learning achievement. This study aims to analyze how the implementation of Cooperative Learning Model in an effort to improve learning achievement of learners on the concept of Ecosystem Learning Materials in students class X 5 semester Even East Negeri Lampung Metro Lampung.

This research is a Classroom Action Research (PTK) which analyzed qualitatively and quantitatively by using field notes method as the main method, which then method of interview and documentation as supporting method in research. The field note method used by the writer to observe carefully the implementation of the action scenario from time to time, noting all the necessary and happening during the implementation of the action during the learning process using the Cooperative Learning model in MA Negeri I Metro Lampung Timur. Interviews conducted by the authors by interviewing teachers and leamers related to the implementation of Cooperative Learning model at MAN I Metro. Documentation used to complement student achievement data and other necessary data.

Implementation of Cooperative Learning model can be able to improve student learning achievement. This is evidenced by the increase in the average value of learning achievement of learners from each cycle that is: In the first cycle, learning achievement learners who reached the completeness of $51.71 \%$ while unfinished reached $48.25 \%$. In cycle II, learning achievement learners who reach the completeness of $81,58 \%$ while learning achievement of unfinished learners reaches 20,67\%. In the third cycle, learning achievement of learners who achieve completeness $89.63 \%$ while learning achievement of unfinished learners reached 10.34\%. Cooperative Learning model applied to Biology subject on the concept of learning material of ecosystem can improve student achievement in class X.5 in MA Negeri I Metro Lampung Timur.
\end{abstract}

Kata Kunci: cooperative learning, Peningkatan prestasi

Perkembangan model pembelajaran dari waktu ke waktu terus mengalami perubahan. Modelmodel pembelajaran tradisional kini mulai ditinggalkan, berganti dengan model yang lebih modern. Sejalan dengan pendekatan kontruktivisme dalam pembelajaran, salah satu model pembelajaran yang kini banyak mendapat respon adalah model pembelajaran kooperatif atau cooperative learning. Model sendiri dapat diartikan sebagai pola atau rencana. Sebagaimana pendapat Isjoni (2009) mengatakan bahwa "Cooperative learning atau pembelajaran kooperatif adalah salah satu bentuk pembelajaran yang berdasarkan faham konstruktivis. Cooperative learning merupakan 
model belajar dengan sejumlah siswa sebagai anggota kelompok kecil yang tingkat kemampuannya berbeda, untuk saling bekerjasama dan membantu memahami materi pelajaran (Isjoni, 2009).

Dari pendapat di atas dapat dipahami bahwa pada model pembelajaran kooperatif ini, peserta didik diberi kesempatan untuk berkomunikasi dan berinteraksi sosial dengan temannya untuk mencapai tujuan pembelajaran, sedangkan guru bertindak sebagai motivator dan fasilitator aktivitas peserta didik. Artinya dalam pembelajaran aktif dengan pengetahuan dibangun sendiri oleh peserta didik dan mereka bertanggung jawab atas hasil pembelajarannya.

Selanjutnya, langkah-langkah model cooperative learning atau pembelajaran kooperatif, sebagaimana pendapat Abdulhak diantaranya, yaitu : merumuskan secara jelas apa yang harus dicapai peserta belajar, (2) memilih bentuk kegiatan pembelajaran yang paling tepat, (3) menjelaskan secara detailproses pembelajaran cooperatif, yaitu mengenai apa yang harus dilakukan, dan apa yang diharapkan, (4) memberikan tugas yang paling tepat dalam pembelajaran, (5) menyiapkan bahan belajar yang memudahkan peserta belajar dengan baik, (6) melaksanakan pengelompokkan peserta belajar, (7) mengembangkan sistem pujian untuk kelompok atau perorangan peserta belajar, (8) memberikan bimbingan yang cukup kepada peserta belajar, (9) menyiapkan instrumen penilaian yang tepat, (10) mengembangkan sistem pengarsipan data kemajuan peserta belajar, baik perorangan maupun kelompok, dan (11) melaksanakan refleksi (Isjoni, 2009).

Dari pendapat di atas, cooperative learning atau pembelajaran gotong royong yaitu sistem pembelajaran yang memberi kesempatan kepada peserta didik untuk bekerjasama dengan siswa lain dalam tugas-tugas terstruktur. Pembelajaran ini hanya berjalan kalau sudah terbentuk suatu kelompok atau suatu tim yang didalamnya siswa bekerja secara terarah untuk mencapai tujuan yang sudah ditentukan . Dari langkahlangkah yang dikemukan di atas, nampaknya dapat dikelompokkan menjadi tiga tahap yakni tahap perencanaan, tahap pelaksanaan dan tahap evaluasi. Kesemuanya ini dimaksudkan agar dapat memperoleh prestasi belajar yang diharapkan.

Prestasi belajar merupakan hasil yang dapat dicapai oleh peserta didik dalam jangka waktu tertentu dan materi pembelajaran tertentu pula sesuai dengan tujuan yang telah disesuaikan dalam tujuan intruksional umum / TIU dan tujuan instruksional umum / TIK.

Menurut Soebandijah bahwa prestasi belajar adalah "penampilan pencapaian seorang peserta didik dalam suatu bidang studi berupa kualitas dan kuantitas hasil kerja peserta didik selama periode waktu yang telah ditentukan yang diukur dengan tes terstandar" (Soebandijah, 1993). Adapun menurut Soepartinah Pakasi bahwa : Prestasi belajar adalah "Hasil yang dicapai murid sesudah ia menjalankan usaha belajar (Pakasi, 1987).

Proses pembelajaran merupakan suatu interaksi antara guru dan peserta didik untuk mencapai tujuan tertentu. Rendahnya prestasi belajar pada pelajaran biologi merupakan indikasi bahwa pelajaran yang dilakukan belum optimal. Salah satu penyebab rendahnya prestasi belajar siswa adalah kurangnya aktivitas siswa dalam proses pembelajaran. 
Berdasarkan hasil pra survey penulis di MA Negeri I Metro, untuk mengetahui proses pelaksanaan pembelajaran kooperatif, terutama bagi guru Biologi materi ekosistem, kelas $\mathrm{X}$, semester 2 tahun pelajaran 2009/2010 nampaknya belum menerapkan model cooperativef ,pembelajaran yang dilakukan hanya menggunakan metode ceramah. belum $\begin{array}{cr}\text { Nampaknya, dikarenakan } \\ \text { melaksanakan model }\end{array}$ pembelajaran cooperatif sehingga prestasi belajar peserta didik MA Negeri I Metro terutama kelas X 6 cenderung masih belum memperoleh hasil yang maksimal. Hal ini dapat dilihat pada tabel berikut ini:

Tabel 1 Nilai Rata-rata Prestasi Belajar Peserta Didik Semester Ganjil Pada Kelas X Di MA Negeri I Metro Tahun Pelajaran 2009/2010

\begin{tabular}{|l|l|l|l|}
\hline No & Kelas & Nilai Rata-rata & Jumlah Sis wa \\
\hline 1 & X 1 & 7,05 & 43 orang \\
\hline 2 & X 2 & 6,75 & 44 orang \\
\hline 3 & X 3 & 6,25 & 45 orang \\
\hline 4 & X 4 & 6,15 & 42 orang \\
\hline 5 & X 5 & 5,25 & 42 orang \\
\hline Jumlah Total & $\mathbf{2 0 6}$ \\
\hline
\end{tabular}

Sumber Data : Buku Leger MA Negeri I Metro TP 2009/2010.

Dari tabel di atas, dapat menunjukkan bahwa prestasi belajar pelajaran Biologi pada semester ganjil tahun pelajaran 2009/2010, diketahui bahwa prestasi belajar biologi masih rendah. "Dilihat Pada daftar nilai kelas menunjukkan bahwa Nilai rata-rata pelajaran Biologi di kelas X. 5 MA Negeri I Metro yaitu 5,25. Hasil ini masih rendah jika dibandingkan dengan nilai ketuntasan belajar yang ditetapkan MA Negeri I Metro yaitu 61 untuk pelajaran IPA Biologi”. Dengan rendahnya prestasi belajar ini, guru

\section{METODE}

Penelitian ini bersifat deskriptif, dengan menggunakan metode penelitian tindakan kelas (PTK). Penelitian tindakan kelas dilaksanakan dalam bentuk siklus yang didalamnya terdapat empat tahapan utama kegiatan, yaitu : "(1) diharapkan untuk memilih model pembelajaran yang tepat pada proses pembelajaran, sehingga dapat meningkatkan semangat belajar peserta didik dan prestasi belajar peserta didik dapat meningkat.

Berdasarkan latar belakang di atas, perlu diadakan penelitian dalam kegiatan belajar dengan menggunakan Model Cooperative Learning sebagai upaya peningkatan prestasi belajar peserta didik kelas VII.5 semester genap MANegeri Tahun Pelajaran 2009/2010.

Tahap perencanaan tindakan,

Tahap pelaksanaan tindakan, (3) Tahap pelaksanaan pengamatan, (4) Refleksi, kemudian dilakukan evaluasi guna menyempurnakan tindakan berikutnya". (Arikunto, 2008) Digambarkan pada gambar 1. 


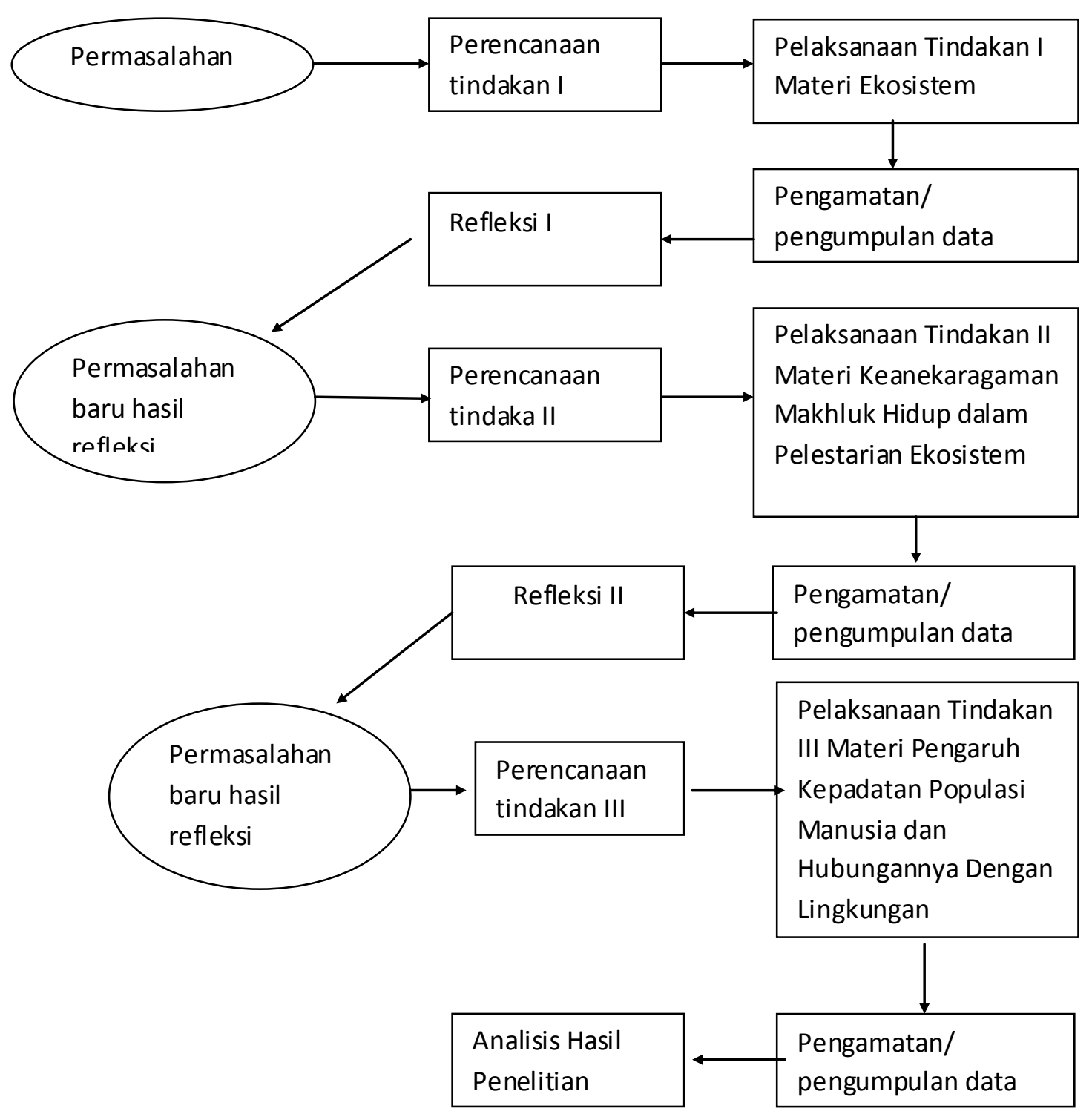

Gambar I Alur penelitian Tindakan Kelas

Populasi dalam penelitian ini adalah seluruh peserta didik MA Negeri I Metro, yang berjumlah 206 peserta didik yang terdiri dari kelas X. 1 Sebanyak 43 orang, X. 2 Sebanyak 44, kelas X. 3 Sebanyak 45 orang, X. 4 sebanyak 42 orang dan X5 sebanyak 42 orang. Sampel dalam penelitian ini adalah siswa kelas VII. 5 MA NegeriI Metro dengan jumlah siswa 42 orang yang memiliki karekteristik yang berbeda di bandingkan dengan kelas $\mathrm{X}$ yang lain yaitu hasil belajar relatif rendah memiliki rata-rata ulangan umum bersama yaitu 5,25 nilai ini masih dibawah kriteria ketuntasan belajar MA Negeri I Metro yaitu 61. Teknik Pengambilan Sampel dalam penelitian ini dengan menggunakan purposive sampel, menurut Margono : 2004 "Purposive sampel didasarkan atas ciri-ciri tertentu yang dipandang mempunyai sangkut paut yang erat dengan ciri-ciri populasi yang telah diketahui sebelumnya, dengan kata lain unit sampel yang dihubungi disesuaikan dengan kriteria-kriteria tertentu yang diterapkan berdasarkan 
tujuan penelitian. (Margono, 2004). Pada penelitian ini penulis menggunakan purposive sampel dikarenakan pada penelitian ini hanya dilakukan pada satu kelas saja yang prestasi belajarnya masih rendah yaitu kelas X. 5 di MA Negeri I Metro.

Teknik pengumpulan data pada Penelitian Tindakan Kelas ini dengan menggunakan :

1. Catatan lapangan, digunakan untuk melakukan pengamatan secara cermat pelaksanaan skenario tindakan dari waktu kewaktu, mencatat semua hal yang diperlukan dan terjadi selama pelaksanaan tindakan berlangsung. Hasil pengamatan yang didapat di gunakan untuk memperbaiki proses pembelajaran pada siklus berikutnya.

2. Interview / wawancara, dipergunakan untuk mewawancarai guru dan peserta didik yang memiliki kriteria kemampuan masing-masing yaitu tiga orang dengan kemampuan rendah, tiga orang dengan kemampuan sedang dan tiga orang dengan kemampuan tinggi dengan menerapkan model pembelajaran Cooperative learning .

3. Dokumentasi, teknik ini digunakan untuk mengumpulkan data prestasi peserta didik dari nilai tes formatif yang dilakukan di akhir sik lus.

Teknik pengumpulan data dari obyek penelitian, maka langkah selanjutnya penulis menganalisa data. Analisis data dapat dilakukan melalui tiga tahapan :

1. Reduksi data, yaitu kegiatan menyeleksi data sesuai dengan fokus masalah. Dimana data yang diperlukan diambil sedangkan data yang tidak perlukan tidak dipergunakan.

2. Mendeskripsikan data, sehingga data yang telah diorganisir menjadi lebih bermakna, mendeskripsikan data bisa dilakukan dalam bentuk naratif, membuat grapik atau menyusunnya dalam bentuk tabel.

3. Membuat kesimpulan berdasarkan deskripsi data. (Sanjaya, 2009)

Data yang akan dianalsis pada penelitian adalah :

Data Kuantitatif berupa data yang diambil dari hasil tes formatif yang dilakukan pada akhir siklus dengan Rumus :

$$
\mathrm{P}=\frac{\mathrm{f}}{\mathrm{N}} 100 \%
$$

Keterangan :

$\mathrm{f}=$ frekuensi yang sedang dicapai persentasenya.

$\mathrm{N}=$ Number of Cases (jumlah frekuensi/banyaknya individu).

$\mathrm{P}=$ Angka persentase. (Sudijono, 2008)

Uji Coba Instrumen Penelitian, tes yang akan diberikan merupakan tes objektif berbentuk pilihan ganda (Multiple Choice) yang terdiri dari 60 butir soal. Sebelum digunakan sebagai instrument penelitian terlebih dahulu diuji cobakan untuk pengujian mengetahui validitas, reliabilitas, taraf kesukaran, dan daya pembeda.

1. Pengujian Validitas

Instrumen yang valid berarti alat ukur yang digunakan untuk mendapatkan data (mengukur) itu valid. Valid berarti instrumen tersebut dapat digunakan untuk mengukur apa yang seharusnya diukur (Sugiono, 2008).

Untuk menghitung validitas butir soal digunakan rumus Product Moment yaitu :

$\mathrm{r}_{\mathrm{XY}}=\frac{N \sum X Y-\left(\sum X\right)\left(\sum Y\right)}{\left\{N \sum X^{2}-\left(\sum X^{2}\right)\right\}\left\{N \sum Y^{2}-\left(\sum Y^{2}\right)\right\}}$

Keterangan :

$\mathrm{r}_{\mathrm{XY}}$ : Validitas suatu butir soal

$\mathrm{N}:$ Jumlah peserta tes

$\mathrm{X}$ : Skor item

$\mathrm{Y}:$ Skor total 
Adapun kreteria untuk validitas butir soal (Arikunto, 2007)

2. Reliabilitas soal

Analisis Reliabilitas suatu tes atau alat ukur lainnya, termasuk non tes, pada hakikatnya menguji keajegan pertanyaan tes apabila diberikan berulang kali pada objek yang sama. Suatu tes dikatakan reliabel atau ajeg apabila beberapa kali pengujian menunjukkan hasil yang relatif sama. (Sudjana, 2005)

Cara yang dapat digunakan dalam menentukan reabilitas adalah menggunakan rumus Kuder Richardson (K-R. 20), yaitu: (Arikunto, 2007)

$$
\mathrm{R}_{11}=\left(\frac{n}{n-1}\right)\left(\frac{S^{2}-\sum p q}{S^{2}}\right)
$$

Keterangan :

$\mathrm{R}_{11}$ : Reliabilitas menggunakan persamaan K-R.20

p: Populasi subyek yang menjawab item dengan benar

q; Populasi subyek yang menjawab item dengan salah $(\mathrm{q}=1-\mathrm{p})$

$\sum$ pq: Jumlah hasil perkalian $\mathrm{p}$ dan $\mathrm{q}$

$\mathrm{n}$ : Banyak soal

S: Standar deviasi atau simpangan baku merupakan akar varian.

\section{Tingkat Kesukaran}

Untuk pengujian taraf kesukaran ini digunakan rumus berikut:

Keterangan:

$$
P=\frac{\sum B}{N}
$$

$P=$ Indeks kesukaran

$\sum B=$ Jumlah siswa yang menjawab soal tes dengan benar

$N \quad=$ Jumlah seluruh peserta didik yang mengikuti tes (Sudjana

Besar tingkat kesukaran soal berkisar antara 0,00 sampai 1,00 yang dapat diklasifikasikan kedalam tiga katagori sebagai berikut ini:

4. Pengujian daya pembeda
Pengujian ini dimaskudkan untuk memperoleh data tentang kemampuan soal dalam membedakan peserta didik yang pandai dengan peserta didik yang kurang pandai. Dapat diukur dengan menggunakan rumusan seperti dibawah ini:

$$
D=\frac{\sum A}{n A}-\frac{\sum B}{n B}=P_{A}-P_{B}
$$

Keterangan:

$D=$ Indeks daya pembeda

$\sum A=$ Jumlah peserta tes yang menjawab benar pada kelompok atas $\sum B=$ Jumlah peserta tes yang menjawab benar pada kelompok bawah

$n A=$ Jumlah peserta tes kelompok atas

$n B=$ Jumlah peserta tes kelompok bawah

$P_{A}=$ Proporsi peserta kelmpok bawah yang menawab soal itu dengan benar $P_{B}=$ Proporsi peserta kelompok bawah yang menjawab benar

\section{HASIL}

MA Negeri I Metro terletak di Metro Lampung Timur tepatnya di desa Bandarrejo jalan lembayung 38B. Keadaan peserta didik MA Negeri I Metro kelas X pada tahun 2009/2010 yang terdiri dari 206 Peserta didik yang masing-masing kelas X.1 berjumlah 43 pesera didik, X.2 berjumlah 44 peserta didik, X.3 berjumlah 45 peserta didik, X.4 berjumlah 42 peserta didik dan X.5 berjumlah 42 Peserta didik.

MA Negeri I Metro telah memiliki kondisi gedung yang permanen dan dalam keadaan baik serta difungsikan dengan baik. Adapun rinciannya ruang kepala sekolah berjumlah 1, ruang guru berjumlah 1 , ruang perpustakaan 1 , ruang belajar berjumlah 13, ruang laboratorium komputer 1, ruang laboratorium IPA 1,ruang BK, ruang WC guru berjumlah 1, ruang WC siswa 
berjumlah 4. selain itu terdapat halaman yang sangat luas, yang dapat digunakan untuk kegiatan olah raga dan kegiatan lainnya, sedangkan masjid sebagai sarana pendukung kegiatan praktek ibadah terletak di dalam lingkungan sekolah.

Tabel 2. Distribusi Frekuensi Relatif (Distribusi Persentase) Hasil Post Test Prestasi Belajar Peserta Didik Pada Siklus I

\begin{tabular}{|l|l|l|}
\hline Nilai $(\boldsymbol{X})$ & $\boldsymbol{f}$ & Persentase $(\boldsymbol{p})$ \\
\hline $0-30,76$ & 2 & 6,89 \\
\hline $31,86-39,86$ & 1 & 3,44 \\
\hline $40,96-48,96$ & 3 & 10,34 \\
\hline $49,06-57,06$ & 8 & 27,58 \\
\hline $58,16-66,16$ & 4 & 13,79 \\
\hline $67,26-75,26$ & 6 & 20,68 \\
\hline $76,36-84,36$ & 5 & 17,24 \\
\hline $85,46-93,46$ & 0 & 0 \\
\hline $94,56-102,56$ & 0 & 0 \\
\hline & $\mathbf{2 9}=\mathbf{N}$ & $\mathbf{9 9 , 9 6}=\mathbf{\Sigma p}$ \\
\hline Total & & \\
\hline
\end{tabular}

Tabel 3. Distribusi Frekuensi Relatif (Distribusi Persentase) Hasil Post Test Prestasi Belajar Peserta Didik Pada Siklus II

\begin{tabular}{|l|l|l|}
\hline Nilai $(\boldsymbol{X})$ & $\boldsymbol{f}$ & Persentase $(\boldsymbol{p})$ \\
\hline $0-35,71$ & 2 & 6,89 \\
\hline $36,81-44,81$ & 2 & 6,89 \\
\hline $45,91-53,91$ & 2 & 6,89 \\
\hline $54,01-62,01$ & 5 & 17,24 \\
\hline $63,11-71,11$ & 9 & 31,03 \\
\hline $72,21-80,21$ & 7 & 24,13 \\
\hline $81,31-89,31$ & 1 & 3,44 \\
\hline $90,41-98,41$ & 1 & 3,44 \\
\hline $99,51-107,51$ & 0 & 0 \\
\hline Total & $\mathbf{2 9}=\mathbf{N}$ & $\mathbf{9 9 , 9 5}=\mathbf{\Sigma} \mathbf{p}$ \\
\hline
\end{tabular}

Tabel 4. Distribusi Frekuensi Relatif (Distribusi Persentase) Hasil Post Test Prestasi Belajar Peserta Didik Pada Siklus III

\begin{tabular}{|l|l|l|}
\hline Nilai $(\boldsymbol{X})$ & $\boldsymbol{f}$ & Persentase $(\boldsymbol{p})$ \\
\hline $0-41,66$ & 3 & 10,34 \\
\hline $42,76-49,76$ & 0 & 0 \\
\hline $50,86-57,86$ & 0 & 0 \\
\hline $58,96-65,96$ & 5 & 17,24 \\
\hline
\end{tabular}




\begin{tabular}{|l|l|l|}
\hline $66,06-73,06$ & 5 & 17,24 \\
\hline $74,16-81,16$ & 7 & 24,13 \\
\hline $82,26-89,26$ & 8 & 27,58 \\
\hline $90,36-97,36$ & 1 & 3,44 \\
\hline $98,46-105,46$ & 0 & 0 \\
\hline & $\mathbf{2 9}=\mathbf{N}$ & $\mathbf{9 9 , 9 7}=\mathbf{\Sigma} \mathbf{p}$ \\
Total & & \\
\hline
\end{tabular}

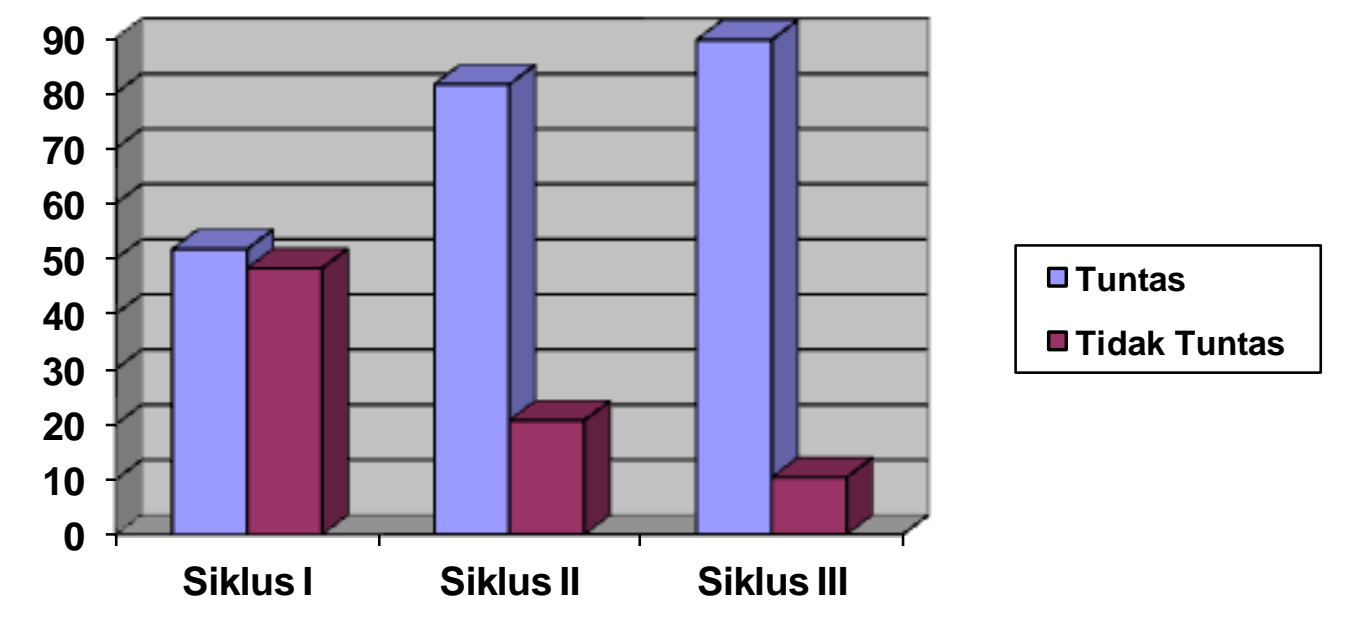

Gambar 2. Diagram Ketuntasan Prestasi Belajar Peserta didik Pada Siklus I, II dan III
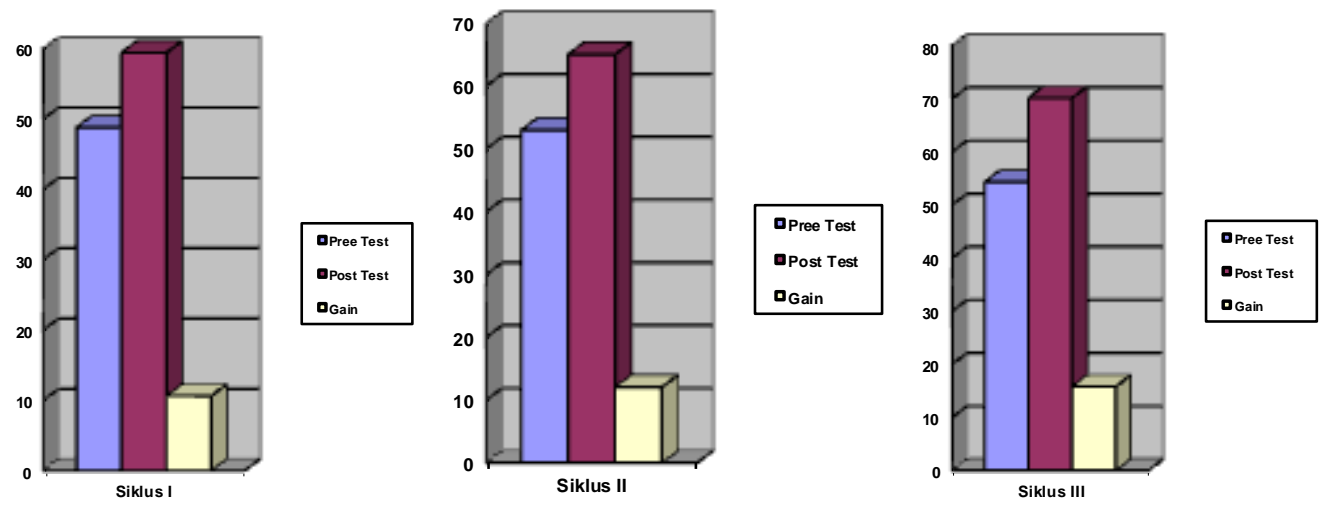

Gambar 3. Diagram Nilai Rata-rata Pree Test, Post Test, dan Gain Pada Siklus I, II dan III

\section{PEMBAHASAN}

Pembelajaran Biologi di MA Negeri I Metro 2 kali dalam seminggu yaitu hari Selasa dan kamis dengan alokasi waktu 2 x 40 menit. Penelitian ini dilaksanakan dalam tiga siklus.
Pada siklus I dengan materi yang dipelajari Ekosistem. Pada siklus II dengan materi yang dipelajari Lingkungan yang terdir dari lingkungan abiotik dan lingkungan biotik. Dan sikus III dengan materi 
yang di pelajari Lingkungan yang terdiri dariproduktivitas primer dan produktivitas sekunder. Sebelum pembelajaran dilaksanakan terlebih dahulu peneliti melakukan konsultasi bersama guru mitra untuk menetapkan pendekatan pembelajaran yang dilakukan. Dilanjutkan dengan menyiapkan perangkat pembelajaran seperti silabus, rencana pelaksanaan pembelajaran, lembar kerja peserta didik, catatan lapangan, dan lembar soal. Dari catatan lapangan dan data prestasi hasil belajar maka dapat dilihat sebagai berikut :

\section{Siklus I}

a. Peroses Belajar Mengajar

Pada siklus I dilaksanakan pada hari Kamis 20 Mei 2010 di hadiri oleh 39 peserta didik yang terdiri dari 22 peserta didik laki-laki dan 17 peserta didik perempuan. Sebelum pembelajaran dikelas dilakukan, observer bersama guru telah menyiapkan perangkat pembelajaran seperti silabus, rencana pelaksanaan pembelajaran, lembar kerja siswa, catatan lapangan, dan lembar soal, kemudian menyiapkan alat dan bahan yang akan digunakan dalam kegiatan belajar mengajar.

Di awal kegiatan pembelajaran guru membuka pelajaran dengan terlebih dahulu mengajak peserta didik membaca do'a bersama, dan mengabsensi peserta didik, kemudian melakukan apersepsi dengan menanyakan "Pernahkah kamu melihat aquarium?" peserta didik menjawab dengan baik. Kemudian guru melakukan motivasi dengan menanyakan "komponen ekosistem terdiri dari berapa dan apa saja?" Peserta didik menjawab dengan baik. Guru membagikan soal pree test kepada peserta didik dan memerintahkan peserta didik untuk menjawab soal tersebut. Peserta didik menjawab dengan baik soal yang telah di berikan, kemudian dikumpulkan kembali kepada guru.

Selanjutnya

menerangkan Ekosistem dan mengkaitkan pembelajaran dengan pengetahuan awal peserta didik. Akan tetapi pada tahap ini guru masih terlalu banyak menerangkan materi tersebut. Kemudian guru membimbing peserta didik membuat kelompok yaitu sesuai dengan nomor diri, memberikan lembar kerja siswa kepada setiap kelompok. Setelah menerima lembar kerja, peserta didik ditugaskan untuk berkumpul sesuai dengan tim ahli yang telah ditentukan untuk berdiskusi, setelah itu peserta didik kembali ke kelompok asal (home group) dan menjelaskan dalam kelompoknya (tutor sebaya). Pada tahap ini peserta didik belum terlalu aktif dalam mempresentasikan hasil kerja kelompoknya. Karena waktu yang terbatas guru belum sempat memberikan kesimpulan terhadap hasil kerja peserta didik. Kemudian guru memberikan soal pree test kepada peserta didik untuk di jawab dengan baik. Peserta didik menjawab dengan baik lalu mengumpulkan soal yang telah dijawab kepada guru kembali. b. Prestasi Belajar Peserta Didik

Tes yang dilaksanakan pada siklus ini mencakup materi ekosistem. soal yang dibuat pada pretest dan postest sama yaitu sebanyak 13 soal pilihan ganda yang sebelum di ujikan kepada kelas yang diteliti terlebih dahulu telah di ujikan pada kelas lain. Pada siklus I ini prestasi belajar peserta didik yang diperoleh melalui nilai pree test, rata-rata hanya 48,80 , pada post test nilai rata-ratanya yaitu 59,42 dan gain rata-rata yang diperoleh sebesar 10,62. Prestasi belajar peserta didik yang mencapai ketuntasan 51,71\% sedangkan yang tidak tuntas mencapai $48,25 \%$. Dengan demikian dilihat dari nilai rata-rata postes yang diperoleh peserta didik setelah mengikuti 
pembelajaran Cooperative Learning masih dibawah kriteria ketuntasan minimal yang ditetapkan guru MTs Negeri Sukoharjo yaitu 61 maka dapat dilihat juga peserta didik yang telah mencapai ketuntasan belajar hanya $51,71 \%$, dimana yang diharapkan peserta didik $85 \%$ dapat mencapai kriteria ketuntasan yang telah ditentukan.

c. Refleksi Siklus I

Keaktifan peserta didik masih kurang karena belum terbiasa dengan teknik jigsaw yang diterapkan peneliti. Begitupun dengan guru dalam mengajar masih belum terbiasa dengan teknik jigsaw yang diterapkan. Kendala-kendala yang dirasakan guru pada pelaksanaan siklus I adalah masih banyak peserta didik belum jelas tentang prosedur pembelajaran Cooperative Learning dengan teknik jigsaw. Waktu yang digunakan pada saat diskusi terlalu pendek dan masih ada peseta didik yang kurang serius mengerjakan lembar kerja dan kurangnya aktivitas peserta didik dalam memperhatikan penjelasan teman, bertanya dan menyanggah pendapat teman pada saat diskusi, serta kelas belum terkondisionalkan untuk tidak ribut.

d. Rekomendasi Perbaikan Rencana Tindakan II

Berdasarkan refleksi siklus I, direkomendasikan perbaikan untuk siklus II sebagai berikut :

1) Mempertahankan kinerja yang sudah baik pada proses pembelajaran siklus I untuk tetap di lakukan pada siklus II.

2) Memperpendek waktu saat menjelaskan materi.

3) Mengarahkan peserta didik saat berdiskusi di dalam kelompoknya.

4) Guru lebih meningkatkan pengelolaan kelas.

\section{Siklus II}

a. Proses Belajar Mengajar

Pada siklus II dilaksanakan pada hari Selasa 25 Mei 2010 di hadiri oleh 39 siswa yang terdiri dari 22 peserta didik laki-laki dan 17 peserta didik perempuan. sebelum pembelajaran dikelas dilakukan, observer bersama guru telah menyiapkan perangkat pembelajaran seperti silabus, rencana pelaksanaan pembelajaran, lembar kerja peserta didik, catatan lapangan, dan lembar soal, kemudian menyiapkan alat dan bahan yang akan digunakan dalam kegiatan belajar mengajar.

Di awal kegiatan pembelajaran guru membuka pelajaran dengan terlebih dahulu mengajak peserta didik membaca do'a bersama, dan mengabsensi peserta didik, kemudian melakukan apersepsi dengan menanyakan "Makhluk hidup dinyatakan tergolong langka apabila?" peserta didik menjawab dengan baik. Kemudian guru melakukan motivasi dengan menanyakan "Upaya pelestarian pada hewan dapat dilakukan dengan cara ?". Peserta didik menjawab dengan baik. Guru membagikan soal pretest kepada peserta didik dan memerintahkan peserta didik untuk menjawab soal tersebut. Peserta didik menjawab dengan baik soal yang telah di berikan, kemudian dikumpulkan kembali kepada guru.

Selanjutnya guru menerangkan tentan Ekosistem secara singkat mengkaitkan pembelajaran dengan pengetahuan awal peserta didik. Kemudian guru membimbing peserta didik membuat kelompok sesuai dengan nomor diri, memberikan lembar kerja peserta didik kepada setiap kelompok. Setelah menerima lembar kerja, peserta didik ditugaskan untuk berkumpul sesuai dengan tim ahli yang telah ditentukan untuk 
berdiskusi, setelah itu peserta didik kembali ke kelompok asal (home group) dan menjelaskan dalam kelompoknya (tutor sebaya). Pada tahap ini peserta didik sudah mulai aktif dalam mempresentasikan hasi kerja kelompoknya meski belum optimal. Guru memberikan kesimpulan terhadap hasil kerja peserta didik. Akan tetapi peserta didik belum sempat di ajak untuk menyimpulkan karena terbatasan waktu, kemudian guru memberikan soal pree test kepada peserta didik untuk dijawab dengan baik. Peserta didik menjawab dengan baik lalu mengumpulkan soal yang telah dijawab kepada guru kembali.

b. Prestasi Belajar Peserta Didik

Tes yang dilaksanakan pada siklus ini mencakup materi Ekosistem. Soal yang dibuat pada pree test dan post test sama yaitu sebanyak 14 soal pilihan ganda yang sebelum di ujikan kepada kelas yang diteliti, terlebih dahulu telah di ujikan pada kelas lain. Pada siklus II ini prestasi belajar peserta didik yang diperoleh melalui nilai pree test, rata-rata hanya 52,95, rata-rata nilai post test yaitu 65,02 dan nilai rata-rata gainnya yaitu 12,07 . peserta didik yang mencapai ketuntasan $81,58 \%$ sedangkan prestasi belajar peserta didik yang tidak tuntas mencapai $20,67 \%$. Ketidak tuntasan sebesar $20,67 \%$ dirasakan mendekati optimal dikarnakan peserta didik sebagian besar sudah menguasai materi pembelajaran dengan cara pendekatan pembelajaran Cooperative Learning yang diterapkan.

c. Refleksi Siklus II

Pada siklus II ini pelaksanaan pembelajaran Cooperative Learning sudah berjalan. Secara umum guru telah menerapkan model pembelajaran Cooperative Learning dengan teknik jigsaw dengan baik tetapi belum sempurna. Keaktifan peserta didik masih kurang meskipun pembelajaran dengan teknik jigsaw telah diterapkan pada siklus I. Masih ada peserta didik yang kurang serius dalam mengerjakan Lembar kerja.

c. Rekomendasi Perbaikan Rencana Tindakan Siklus III

Berdasarkan refleksi siklus II, direkomendasikan perbaikan untuk siklus III sebagai berikut :

1) Mempertahankan kinerja yang sudah baik pada proses pembelajaran siklus II untuk tetap di lakukan pada siklus III.

2) Mengarahkan peserta didik agar lebih aktif menderkan penjelasan guru dan teman, sehingga peserta didik tidak malu untuk menjelaskan, bertanya dan mengungkapkan pendapatnya kepada teman kelompoknya.

3) Guru lebih meningkatkan pengelolaan kelas.

\section{Siklus III}

a. Proses Belajar Mengajar

Pada siklus III dilaksanakan pada hari Kamis 27 Mei 2010 di hadiri oleh 39 peserta didik yang terdiri dari 22 peserta didik laki-laki dan 17 peserta didik perempuan. sebelum pembelajaran dikelas dilakukan observer bersama guru telah menyiapkan perangkat pembelajaran seperti silabus, rencana pelaksanaan pembelajaran, lembar kerja peserta didik, catatan lapangan, dan lembar soal, kemudian menyiapkan alat dan bahan yang akan digunakan dalam kegiatan belajar mengajar.

Di awal kegiatan pembelajaran guru membuka pelajaran dengan terlebih dahulu mengajak peserta didik membaca doa bersama, dan mengabsensi peserta didik, kemudian melakukan apersepsi dengan menanyakan "Hal apa saja yang mempengaruhi populasi manusia?", peserta didik menjawab dengan baik. Kemudian guru melakukan motivasi dengan menanyakan " Apa saja 
macam-macam dampak ledakan penduduk?" Peserta didik menjawab dengan baik. Guru membagikan soal pree test kepada peserta didik dan memerintahkan peserta didik untuk menjawab soal tersebut. Peserta didik menjawab dengan baik soal yang telah di berikan. Kemudian dikumpulkan kembali kepada guru.

Selanjutnya guru menerangkan tentang Kepadatan Populasi Manusia Hubungannya dengan Lingkungan secara singkat mengkaitkan pembelajaran dengan pengetahuan awal peserta didik. Kemudian guru membimbing peserta didik membuat kelompok berdasarkan nomor diri, memberikan lembar kerja peserta didik kepada setiap kelompok. Setelah menerima lembar kerja, peserta didik ditugaskan untuk berkumpul sesuai dengan tim ahli yang telah ditentukan untuk berdiskusi, setelah itu peserta didik kembali ke kelompok asal (home group) dan menjelaskan dalam kelompoknya (tutor sebaya). Pada tahap ini peserta didik sudah aktif dalam mempresentasikan hasil kerja kelompoknya. Guru bersama-sama peserta didik menyimpulkan hasil kerja peserta didik tentang Kepadatan Populasi Manusia dan Hubungannya dengan Lingkungan kemudian guru memberikan penguatan tentang materi tersebut. Kemudian guru memberikan soal post test kepada peserta didik untuk dijawab dengan baik. Peserta didik menjawab dengan baik lalu mengumpulkan soal yang telah dijawab kepada guru kembali.

b. Prestasi Belajar Peserta Didik

Tes yang dilaksanakan pada siklus ini mencakup materi Kepadatan Populasi Manusia Hubungannya dengan Lingkungan. Soal yang dibuat pada pree test dan post test sama yaitu sebanyak 12 soal pilihan ganda yang sebelum di ujikan kepada kelas yang diteliti terlebih dahulu telah di ujikan pada kelas lain. Pada siklus III ini prestasi belajar peserta didik yang diperoleh melalui nilai pree test, rataratanya hanya 54,31, rata-rata nilai post test yaitu 70,11 dan nilai rata-rata gainnya yaitu 15,81 . Peserta didik yang mencapai ketuntasan 89,63\% sedangkan prestasi belajar peserta didik yang tidak tuntas mencapai 10,34\%. Dari ketuntasan tersebut peneliti merasa telah mencapai kriteria yang diharapkan dimana hanya $10,34 \%$ peserta didik yang belum mencapai kriteria ketuntasan yang ditetapkan.

\section{c. Refleksi}

Pada siklus III ini pelaksanaan pembelajaran Cooperative Learning sudah lebih baik dari siklus sebelumnya. Hal ini terlihat adanya peningkatan rekomendasi perbaikan rencana tindakan pada siklus II yaitu :

1) Guru telah mengarahkan peserta didik agar lebih aktif menderkan penjelasan guru dan teman, sehingga peserta didik tidak malu untuk menjelaskan dan bertanya serta mengungkapkan pendapatnya terhadap teman kelompoknya.

2) Guru sudah dapat menguasai kelas pada kegiatan pembelajaran serta waktu yang cukup dalam proses pembelajaran sehingga pembelajaran Cooperative Lerning berjalan dengan baik.

3) Adanya peningkatan ketuntasan prestasi belajar peserta didik dari setiap siklus.

\section{KESIMPULAN}

Berdasarkan hasil temuan yang diperoleh dari penelitian tentang penerapan model cooperative learning dalam upaya peningkatan prestasi belajar peserta didik pada kelas X. 5 yang dilaksanakan di MA Negeri I Metro Lampung Timur, maka penulis mengemukakan kesimpulan sebagai berikut : 
1. Dengan menerapkan model Cooperative Learning pada mata pelajaran Biologi, peserta didik akan termotivasi untuk belajar lebih giat dan mau berpikir terhadap materi yang diberikan oleh guru, karena keberhasilan kelompok tersebut tergantung kepada terpenuhinya tanggung jawab setiap anggota (individual) dari kelompok tersebut.

2. Dengan pembelajaran model Cooperative Learning ini adalah mempermudah guru dalam menyampaikan materi pelajaran, karena dalam penyampaian materinya guru dibantu oleh beberapa peserta didik dari kelompok ahli, sehingga keefektifan dan keefisienan dalam proses pembelajaran akan tercapai secara maksimal.

3. Dengan menggunakan model Cooperative Learning terutama tipe Jigsaw pada konsep saling ketergantungan dalam ekosistem mengalami peningkatan yang sangat baik. Hal ini dibuktikan dengan adanya peningkatan nilai rata-rata prestasi belajar peserta didik dari tiap siklus, diantaranya : Pada siklus I, Prestasi belajar peserta didik yang mencapai ketuntasan yaitu 51,71 \% sedangkan yang tidak tuntas mencapai 48,25\%. pada siklus II prestasi peserta didik yang mencapai ketuntasan yaitu $81,58 \%$ sedangkan prestasi belajar peserta didik yang tidak tuntas mencapai 20,67\%. pada siklus III prestasi peserta didik yang mencapai ketuntasan 89,63\% sedangkan prestasi belajar peserta didik yang tidak tuntas mencapai $10,34 \%$.

\section{SARAN}

Dari hasil penelitian ini, sebagai bahan rekomendasi mempertimbangkan hasil temuan baik di lapangan maupun secara teoritis, maka beberapa hal yang dapat menjadi bahan rekomendasi adalah sebagai berikut:

1. Bagi Sekolah

Agar proses pembelajaran yang dilaksanakan di sekolah dapat memberikan hasil yang maksimal, hendaknya selain memberikan kebebasan kepada guru untuk menentukan metode pembelajaran yang tepat, maka pihak sekolah harus dapat memfasilitasi berbagai kebutuhan untuk dapat melaksanakan model pembelajaran tersebut, seperti terpenuhinya kebutuhan akan sarana dan prasarana pembelajaran.

2. Bagi Peserta Didik

Jika ingin memperoleh prestasi belajar yang maksimal pada mata pelajaran Biologi dengan menggunakan model cooperative learning, maka peserta didik perlu meningkatkan kemampuan dalam belajar, baik secara pribadi ataupun atas dasar bimbingan guru, orang tua dan teman sekelasnya yang lebih mengerti, agar prestasi belajar yang ditunjukan dalam bentuk kognitif lebih meningkat lagi.

3. Bagi Peneliti Lain

Sebaiknya mengadakan penelitian yang lebih lanjut terhadap faktorfaktor yang menyebabkan rendahnya prestasi belajar peserta didik selain model pembelajaran.

\section{DAFTAR PUSTAKA}

Sudijono, A. 2010. Cooverative Learning (Mempraktikkan Cooperative Learning di RuangRuang Kelas). Jakarta : PT Grasindo

Isjoni. 2009. Cooperative Learning (Efektifitas Pembelajaran Kelompok). Bandung : Alfabeta 
Margono. 2004. Metodologi Penelitian Pendidikan. Jakarta : Rineka Cipta

Sudjana, N. 2005. Penilaian Hasil Proses Belajar mengajar. Band ung : Rosdakarya

Soebandijah. 1993. Pengembangan dan Inovasi Kurikulum. Jakarta : Rajawali

Pakasi, S. 1993. Anak dan Perkembangannya. Jakarta : Gramedia

Sugiono. 2008. Metode Penelitian Pendidikan Pendekatan Kuantitatif dan Kualitatif. Bandung : Alfabeta

Arikunto, S. 2007. Dasar-Dasar Evaluasi Pendidikan (Edisi Revisi). Jakarta : Bumi Aksara.

Arikunto, S. 2008. Penelitian Tindakan Kelas. Jakarta. Kencana

Sanjaya, W. 2009. Penelitian Tindakan Kelas. Jakarta. Kencana 